\title{
ПАЛЛИАТИВНАЯ ТЕРАПИЯ И КАЧЕСТВО ЖИЗНИ БЕЗНАДЕЖНО БОЛЬНЫХ ПАЦИЕНТОВ: ЭТИЧЕСКИЙ АСПЕКТ
}

\section{PALLIATIVE THERAPYAND QUALITY OF LIFE IN RELIABLE PATIENTS: ETHICAL ASPECTS}

\section{Z. Abdulaeva}

Summary: In Russia, the problem of hopeless patients suffering from incurable diseases is very acute. The article discusses the goals, objectives, essence of palliative medicine and possible prospects for its development from the standpoint of ethics. The author highlights a holistic approach to providing assistance in the terminal state.

Keywords: terminal condition, death, palliative care, hospice, quality of life, ethics.
«Хоспис - это дом, в котором соединяются высочайший гуманизм и профессионализм...» Академик Дмитрий Лихачев

$\mathrm{y}$ жизни есть две важные точки - это рождение и смерть. Мы успешно родились и перед нами вопрос как нам столь же успешно умереть. Еще в древние времена люди пытались помочь и поддержать друг друга во время болезни и в преддверии надвигающейся смерти. Умирающего человека окружала обстановка таинственности и торжественности. В древнем мире смерть не считалась личным делом, так как ценность человека жестко зависела от выполнения им социальных функций в обществе.

Болезнь и смерть есть и всегда будут неизбежной частью человеческого опыта. По тому, как общество заботится о детях, престарелых и умирающих, судят о зрелости этого общества. Основы благополучной старости закладываются с детства. Соответственно, важно выработать такое отношение к смерти, как к закономерному этапу пути человека.

В философской традиции, идущей от Августина к Паскалю, Кьеркегору, и далее экзистенционализму, страдания человека рассматриваются как ценности, необходимые для выражения эмоциональной полноты бытия, прихода к высшему смыслу, понимаемому как соединение с Богом при сохранении сознания «Я». По мысли Паскаля, страдание, необходимое как шаг на пути к смерти, выступает как результат культивирования состояния тревоги, тоски, способствующему высокому трагическому накалу души.

\author{
Абдулаева Заира Эсенбулатовна \\ К.ф.н., дочент, Дагестанский государственный \\ медицинский университет \\ zaina1972@mail.ru
}

Аннотация: В России очень остро стоит проблема безнадежных больных страдающих неизлечимыми заболеваниями. В статье рассматриваются цели, задачи, сущность паллиативной медицины и возможные перспективы его развития с позиций этики. Автором выделяется холистический подход к оказанию помощи в терминальном состоянии.

Ключевые слова: терминальное состояние, смерть, паллиативная помощь, хоспис, качество жизни, этика.

Л. Карсавин в «Поэме о смерти» говорит о всеобщем характере страдания, которая пронизана и жизнь, и смерть, и посмертное бытие. Страдание предстает как причастие мира и тем самым отвергается рационалистический оптимизм, признающий отсутствие страдания как благо. По мере того, как смерть все больше вытесняется из жизненного пространства человека, из его жилища, появляются специальные дома «дома мертвых». Постепенно «торжественная смерть» в семейном кругу уходит из европейской цивилизации. [1,с.243]

В прошлом люди умирали неожиданно. Постоянный прогресс в медицине позволяет жить нам дольше, но одновременно мы переживаем длительные физические и моральные переживания и изоляцию от общества. Поэтому, главное усилие в оказании помощи безнадежному больному должно быть направлено на то, чтобы не позволить болезни, страданиям и боли господствовать над человеком, т.е. купирование боли и других патологических симптомов, а также решение социальных, психологических и духовных проблем больных.

Пугает возрастающее число сторонников активной эвтаназии, особенно среди студентов-медиков. Практику эвтаназии они находят приемлемой не только для себя, но и для самых близких. Основные причины оправдания эвтаназии: депрессия, экзистенциальные страдания, утрата независимости, боязнь стать обузой для семьи и общества, бедность. Большинство таких людей в нашей стране не имеют средств для проведения полноценного лечения.

«Можно утверждать, что во всех больницах России 
распространена такая практика, когда больного, находящегося в терминальном состоянии, по просьбе самого больного или его родственников, а зачастую по подсказке врачей, выписывают из больницы домой (как говорят в народе, «выписали умирать»). Ясно, что это не во всех случаях означает прекращение оказания ему медицинской помощи, прекращение усилий врачей по спасению его жизни. Эти мероприятия могут быть продолжены и дома. И все-таки в значительной части подобных случаев такие больные остаются без интенсивных мер терапии, лечение ограничивается попытками создать ему возможный физический и психический покой. А это и есть пассивная эвтаназия. И такое решение нередко принимается не консилиумом, не этическим комитетом, а лечащим врачом единоличHO» $[2$, с.148]

Моральная проблема заключается в том, что многие врачи и общественные деятели высказывают мнение, что на принятие решения самим больным о выписке его из больницы домой может влиять не столько тяжесть его состояния и страдания, сколько отсутствие альтернативы, особенно отсутствие возможностей обеспечить умирающему максимальную поддержку и помощь, улучшить качество его жизни.

С целью облегчения страданий инкурабельного больного, в том числе умирающего, зарождается паллиативная помощь. (и хоспис как ее компонент для оказания помощи в конце жизни)

Паллиативная помощь - направление медико-сочиальной деятельности, челью которого является улучшение качества жизни больных и их семей, оказавшихся перед лицом смертельного заболевания.

Кроме того, в новом определении период оказания помощи выходит за рамки периода болезни и включает в себя необходимость поддержки близких и после смерти пациента, которые переживают тяжелую утрату.

Облегчение бремени лечения и ухода за безнадежными больными достигается соблюдением трех основных принципов: эффективное симптоматическое лечение, борьба с болью; максимальное повышение качества жизни; всесторонняя реабилитация характерного заболевания, качественно ограничивающего жизнедеятельность человека.

До последнего времени не подчеркивалась важность обучения и профессиональной подготовки в области этих обширных разделов помощи.

Холистический подход к оказанию помощи - это хорошее качество медицинского обслуживания, что чрезвычайно важно в паллиативной помощи.
Множественные опросы подтверждают мнение о том, что желание умереть у больных с тяжелыми, причиняющими страдания, неизлечимыми заболеваниями, связано с отказом от именно такой жизни, а не от жизни вообще. Поэтому единственной альтернативой эвтаназии, на сегодняшний день, является организация хосписов и предоставление качественной паллиативной помощи, хотя этико-философские основания современной паллиативной медицины являются по ряду вопросов спорными.

Современная философия, а также основные революционные положения хосписной и паллиативной помощи, впервые были сформулированы и опубликованы C. Saunders в журнале для медсестер Великобритании: "Nursing Times"в 1961 г. C. Saunders подчеркивала, что необходимо прежде всего обратить внимание на пациента, а не на его болезнь, и впервые представила концепцию «совокупной боли», что включает в себя не только физическую боль, но и психологическую, и душевную.

Принципы хосписной и паллиативной помощи:

- утверждать жизнь и рассматривать смерть как нормальный процесс;

- не ускорять и не отсрочивать смерть;

- облегчать боль и другие тягостные симптомы;

- учитывать психологические и духовные аспекты помощи;

- предлагается система помощи, которая обеспечивает больным возможность жить настолько активно, насколько это возможно, до самой смерти;

- предусматривается система помощи семье пациента во время его болезни, а также после его смерти.

К сожалению, не только в широких кругах, но даже и среди медицинских работников, существует несколько искаженное представление и сущности паллиативной помощи.

Исходная идея хосписа очень проста: умирающий нуждается в особой помощи, ему можно и должно помочь пройти через границу жизни и смерти.

На протяжении многих лет сторонникам C. Saunders приходилось и приходится преодолевать множество препятствий, среди которых - профессиональная черствость по отношению к терминальным больным и табу на открытое обсуждение проблемы умирания как среди медицинских работников, так и в обществе в целом. Очень мало внимания обращается на последние моменты жизни человека. С одной стороны жизнь поддерживается только с помощью медицины, а с другой люди чувствуют себя брошенными.

В России первый хоспис был открыт в 1990 г. в Санкт- 
Петербурге по инициативе английского журналиста В. Зорза и врача-психотерапевта А.В. Гнездилова, а также при активной поддержке общественности, в частности академика Д.С. Лихачева и писателя Д.А. Гранина.

В настоящее время паллиативная медицинская помощь осуществляется в соответствии с идеями концепции качества жизни и предполагает использование в соответствии с конкретной ситуацией экстраординарных и ординарных средств медицинской помощи. Эксперты BO3 и Римско-католическая церковь (в лице Папы Пия XII) признали нецелесообразным применять экстраординарные медицинские средства в случаях, когда пациент находится в терминальном состоянии. Это новое понимание гуманного отношения к умирающему пациенту-не использовать имеющиеся в арсенале медицины методы и средства для продления процесса умирания человека, который, как правило, сопровождается физическими и душевными мучениями. Оказание паллиативной помощи не должно оттягивать наступление смерти умирающего человека. Целью паллиативной помощи является достижение наилучшего качества жизни больных и их семей.

Считается, что выбор между ординарным и экстраординарным мерами медицинской помощи должен осуществляться в соответствии с принципом пропорциональности, согласно которому польза от медицинского вмешательства для больного должна превышать степень причиняемого при этом вреда. “Концепция разграничения ординарного и экстраординарного лечения и исторически, и как таковая лежит в основе философии современной паллиативной медицины, призванной способствовать реализации права человека на достойную смерть. ...Прежняя тактика ведения умирающих больных (продления их жизни во что бы то ни стало), если речь о безусловно безнадежных случаях, теперь трактуется как унизительное для больных, бессмысленное пролонгирование умирания, превращение участи тех, кому выпал "ужасный конец", в "ужас без конца". ...Этическая максима безусловно уважения жизни пациента в паллиативной медицины приобретает следующий вид: если невозможно прервать или даже замедлить развитие болезни, если больной обречен, качество жизни, по логике вещей, становится более важным, чем её продолжительность" [3,с.254].
Поэтому, важно помнить, что паллиативная помощь призвана повышать качество жизни пациента, невзирая на предполагаемую небольшую продолжительность жизни.

Диагноз безнадежности и пациентом, и медперсоналом, и окружающими часто воспринимается как приговор, после которого между больным и внешним миром вырастает невидимая стена отчуждения и стигма, а к физическим страданиям добавляется ощущение одиночества, изолированности, чувство обреченности и безысходности. И если пациент видит себя глазами других, будто он исчез, то о чем ему остается просить, если не о скором наступлении смерти? [4,с 244].

Выдающийся русский биолог И.И. Мечников представлял другую позицию. Человек должен как бы изжить себя, устать и заснуть после плавного окончания периода деятельной бодрой старости. В таком подходе сочетается потребность человечества дольше сохранить физическое и психическое здоровье, используя достижения науки и техники, а также спокойное принятие смерти, понимание ее как естественное окончание жизненного цикла.

Касаясь вопроса повышения уровня оказания такой помощи, Дагестан вошел в число пилотных регионов России, для которых не только создаётся индивидуальная программа развития паллиативной помощи, но и обеспечивается ее сопровождение.

«Это одно из тех немногих мест в стране, где не нужно никого обучать философии паллиативной помощи. Забота о пожилых, немощных, вообще забота здесь часть культурного кода», - пояснила Анна Федермессер куратор проекта «Регион заботы» Общероссийского народного фронта (ОНФ), учредитель Фонда помощи хосписам «Вера».Она уточнила, что согласно традициям Дагестана, все тяжелобольные пациенты обязательно проживают последние дни дома. Люди стараются забрать домой даже родственников с психическими заболеваниями - тех, кого из-за уклада общества стараются не афишировать.

«Мы не можем добавить дней к жизни. Мы можем добавить жизни дням».

\section{ЛИТЕРАТУРА}

1. Кетова Т.Н. Жизнь и смерть: по ту сторону метафизики. «Философия человека в историческом контексте» Санкт-Петербург , 2019, Стр. 243.

2. И.А. Шамов. Биомедицинская этика. Махачкала, 2005. С. 148.

3. Иванюшкин А.Я., Хетагурова А.К. История и этика сестринского дела. - М.: ГОУ ВУНМЦ МЗ РФ, 2003, с.254.

4. Вестник Саратовской государственной юридической академии В.И. Порох, В.А. Катрунов, Е.В. Засыпкина. Паллиативная терапия и качество жизни безнадежно больных пациентов № 2 (103) ,2015, стр. (243-244) 